\title{
First Recipient of the Richard Evans Schultes Award
}

$D_{\mathrm{R}}^{\mathrm{r}}$ Calvin R. Sperling, of the National Germplasm Resources Laboratory at the US Department of Agriculture, has been named as the first recipient of the annual Richard Evans Schultes Award for his outstanding contributions to the field of ethnobotany. The award honours the name of Harvard Professor Emeritus and Emeritus Director of the Botanical Museum of Harvard University, Richard Evans Schultes, co-Author (with Robert F. Raufaff) of The Healing Forest: Medicinal and Toxic Plants of the Northwest Amazonia, the sole or joint Author of many other noted works, who is widely recognized as 'the Father of Ethnobotany' - a title bestowed on him by Prince Philip of the UK when he presented Schultes with the Gold Medal of the World Wildlife Fund. 'Calvin Sperling', said Schultes, 'is one of the foremost ethnobotanists today, due to his consistent excellence in field research and to his extensive work to conserve biological diversity and improve crop plants world-wide.'

Sperling, a former student of Schultes' at Harvard, was recognized for his comprehensive work as a field ethnobotanist in the preservation of genetic resources and the ethnobotany of economic plants. 'Although [other] excellent candidates were nominated. Sperling was the unanimous choice of the international [selection] committee.' stated Dr Michael Balick. Curator of Economic
Botany and Director of the New York Botanical Garden's Institute of Economic Botany.

The first annual Richard Evans Schultes Award for outstanding contributions to the field of ethnobotany or to indigenous peoples' issues related to ethnobotany, was presented for 1993 at the 34th meeting of the Society for Economic Botany on June 25 at the Fairchild Tropical Garden in Florida. The Schultes Award features a \$5,000 cash prize donated by Conservation International, a nonprofit organization that supports the conservation of biological diversity world-wide.

The Healing Forest Conservancy, sponsor and administrator of the Schultes Award, was founded in 1989 by Shaman Pharmaceuticals, Inc., a Northern Californiabased company focused on the discovery and development of novel pharmaceuticals from higher plants. The Conservancy is a non-profit foundation dedicated to the conservation of tropical forests and to the welfare of tropical forest peoples.*

Katy Moran, Executive Director The Healing Forest Conservancy 3521 S Street NW

Washington

DC 20007, USA.

* See also the preceding item in this issue. - Ed.

\section{History of the Environmental Movement and Environmental Conservation}

The National Documentation Centre for Environmental and Cultural Studies (CEDEC), based in the French Alps, is an NGO that was founded in 1987 with the goal of managing an extensive environmental library and bookstore focussing on environmental conservation and the pertinent natural sciences. Functioning as a network for members and subscribers to the magazine and catalogue La Bibliothèque Naturaliste, CEDEC promotes reflection on Nature, politics, and 'popular ecology' as well as on ecology relating to human health.

Since 1989, our Centre has undertaken the preparation of an international reference book entitled World History of the Environmental Movement and the Protection of Nature (covering environmental issues, institutions, and NGOs, Green parties, etc.). This work owes its origins to a conviction that without an understanding of history, and without due awareness of our own cultural origins, there cannot be much future for the environmental movement as an effective force in an overcrowded world. There is, therefore, a need to investigate, as Lynn White put it in 1966, 'The historical roots of our ecological crisis', these are in fact 'the roots of the future'.

The importance of the history of environmental conservation is still underestimated in Europe: from cultural, juridical, and institutional, standpoints, very much needs to be done, as also in the recording of key events. At a time when environmental issues are discussed on a global scale, there is, as yet, no at-all-adequate reference work. The world history which we are preparing, while ambitious, is realizable with sufficient help. In particular we are looking for documentation, collaborators, and financial support prior to publication.

We are seeking:

1. Information: local or national histories, chronologies, bibliographies, case studies, reports, and any docu- ment on the environmental movement from its beginning to the present day. We need precise dates (day, month, and year) of landmark events in every country: major congresses and conferences, creation of effective institutions and organizations, juridical and institutional measures, demonstrations, protest campaigns, boycotts, sit-ins, land-use conflicts, pollution and other ecological disasters, results of elections where 'green' candidates have participated, outstanding books, ecodevelopment and reforestation projects, and precise dates of the deaths of well-known personalities.

We ask all people who are actively in environmental protection and management, especially from developing countries, to send us any appropriate material. We are interested in all activities, both governmental and non-governmental, as long as they were of significance in raising public awareness of environmental problems or advances. In particular, we ask for support from the members and associates of IUCN (The World Conservation Union) and of the European Association for Environmental History (Mannheim, Germany), as similarly from other continents.

Although we have written to many NGOs in developing countries, we have not received precise information from the majority of states in Africa, Latin America, and the Middle East.

2. French-speaking collaborators who are able to analyse and summarize books and magazines in English or other languages, in order to establish historical chronologies. This is basically voluntary work, except in special cases.

3. Collaborators abroad, who are able to draw up chronological accounts of environment-related events in their countries or to complete our provisional chronologies (in any language). 